\title{
Budget Allocation of Taxes to Territorial Budgets
}

\author{
Ivana Pařízková*
}

* JUDr. Ivana Pařízková, PhD, Department of Financial Law and Economics, Faculty of Law,
Masaryk University, the Czech Republic. The author specialises in Financial Law, Budget Law and
Tax Law. (e-mail: ivana.parizkova@law.muni.cz)

\begin{abstract}
The contribution deals with the financing of territorial self-governing units in the Czech Republic. The economic basis of local governance is still the most important and the most complicated issue of local governance. Local governances need economic independence for filling their tasks. The aim of this paper is to describe the importance of budget allocation of taxes (BAT) for municipal and regional budgets in the Czech Republic and, on the basis of description and critical analysis or comparison and synthesis of acquired knowledge, to confirm or disprove the hypothesis that partial amendments to the Act on Budget Allocation of Revenue of Certain Taxes to territorial budgets damage municipalities and regions or, on the contrary, strengthen their permanent financial basis. Description, analysis and synthesis are used as a method for writing this article.
\end{abstract}

Keywords: budget allocation; public sector; territorial self-governing unit; the budget; the Czech Republic

\section{Introduction}

The issue of territorial budgets is a topic that is not satisfactorily addressed by law and, as a result, it is often very thorny and debatable, although there are amendments to the law every year or new laws are created. As an example, we can mention Act No. 23/2017 Coll. on the Rules of Budgetary Responsibility, as amended. However, problems still arise as to how much entitlement can be granted to these self-government institutions and how many levels the self-government should have. In order for these self-government units to carry out their tasks and to avoid the disproportionate interference of the state in their activities, these self-government units must necessarily have economic independence, i.e. they must have their own assets and their own funds (resources). This is the so-called economic basis of a municipality and a region, within which the municipality and the region operate independently, under the conditions stipulated by special regulations. ${ }^{1}$ The Act on Municipalities and the Act on Regions define the conditions of the economy only in a framework. They generally refer to the property of municipalities and regions, establish the right of municipalities and regions to manage, based on a contractual principle, also with the property of other entities, and impose on municipalities and regions the obligation to manage according to the budget. ${ }^{2}$ 
Budget allocation of taxes in the Czech Republic or tax allocation as stated in specialised literature determines to which budget the relevant tax or part thereof flows. Tax revenue and, therefore, budget allocation of taxes play a decisive role in terms of revenue of municipal and regional budgets and have a significant impact on their financial stability and autonomy. It is also true that this revenue is not in any way assigned.

Specialised literature often discusses whether budget allocation of taxes is a subsidy or transfer, and what can be considered transfers and subsidies.

In order to be able to answer what is the budget allocation of taxes, first of all, we need to make a brief description of the concept of transfer and subsidy. ${ }^{3}$

Generally speaking, a transfer means transferring capital and, in terms of economics, is considered to be a government payment to other entities for which the government does not receive consideration in the form of production factor services owned by the entities. Transfer payments include, for example, payments of old age and disability pensions, child allowances, maternity allowance or unemployment benefits. Transfer payments in this model are independent of the size of the total pension. A subsidy in economics means a financial donation or a financial reimbursement similar to the donation by the state or territorial self-government unit to the relevant entity, in order to reduce the price of a particular property the provision of which is in the "public interest". For our needs, it is important that the concept of subsidy is defined by budget rules providing that a subsidy means funds of the state budget, state financial assets or the National Fund provided to legal or natural persons for the intended purpose and, at the same time, the law stipulates that the subsidy or refundable financial assistance is not a legal claim unless a specific regulation stipulates otherwise.

Budget allocation of taxes is not a typical subsidy since funds from the collection of taxes are reallocated by determining a specific share for a territorial self-government unit based on a mathematical formula according to established criteria. The state has decided to leave some means of tax revenue to entities other than the state, even though they are derived from it to a certain extent. It is a manifestation of fiscal decentralisation, when decentralisation ensuring the degree of financial self-sufficiency of territorial self-government units takes place in addition to decentralisation of the performance of public administration (powers and activities). Budget allocation of taxes, often abbreviated to BAT, does not constitute direct financial flows between the state budget and territorial budgets, since the collection of the statutory and allocated taxes is immediately divided into precise shares. Reallocation takes place immediately after a selection phase, i.e. before the volume of selected funds becomes part of a specific public budget. Budget allocation is certainly a crucial element in defining the links between the state and territorial selfgovernments in general. The discussion is conducted in the sense of what is considered separate tax revenue and when it is a transfer. ${ }^{4}$

Most confusion is caused by taxes or the share of their revenue. Two situations can be distinguished. If the competent territorial self-government unit can affect the level of taxation by means of certain structural elements of tax such as tax rates or adjusting the tax base of the tax imposed, such revenue is considered to be a separate tax revenue of that territorial self-government unit. However, if a territorial self-government unit has no influence on the structural elements of a tax and this influence is realised only by the central 
government, then the reallocation or allocation of selected revenues is made according to the established criteria. ${ }^{5}$ In this case, such allocation, i.e. the distribution of tax revenue, can be designated as a transfer. ${ }^{6}$ If we accept the tax revenue differentiation thus set, the tax revenue from real estate intended for municipalities will remain the only tax revenue in the true sense of the word for a territorial self-government unit in the Czech Republic. Other so-called tax revenues are already based on the setting of the budget allocation of taxes where the recipient, region and municipality will receive only the determined proportion of tax revenue according to the rules laid down by the law.?

The most important law determining the autonomous revenues of territorial self-government units is Act No. 243/2000 Coll. on Budget Allocation of Revenue of Certain Taxes to Territorial Self-Government Units and to Certain State Funds (the Act on Budget Allocation of Taxes), as amended, which is to ensure their fiscal sufficiency. The existing act allocates tax revenue in such a way that the state budget and territorial self-government budgets are balanced and their fiscal volume develops relatively in agreement. This requirement is achieved by an extended portfolio of shared taxes, which in practice means that the share of municipalities and regions is secured both on progressive taxes and regressive taxes. ${ }^{8}$

Given that tax revenues represent about half of the total revenues in municipalities and regions, it is appropriate to perceive changes in their development since 1993, i.e. since the establishment of the independent Czech Republic and the adoption of a new tax system, and also to see the causes of the necessary changes in budget allocation of taxes to municipalities and regions in particular periods. ${ }^{9}$

\section{The Concept of Budget Allocation, Shared and Assigned Taxes}

Budget allocation generally means either legally defined types of taxes that flow directly to the budgets of municipalities and regions or the statutory share of municipal and regional budgets in the national tax revenue. The issue of budget allocation of taxes is closely related to fiscal decentralisation, which accompanies the general organisational principle in public administration, namely the decentralisation of powers and activities. It is a necessary condition for mutually autonomous decision-making of individual levels of management. Depending on the degree of fiscal decentralisation, we can also assess the applied model of fiscal federalism in the given budget system. The most common, combined model sets own revenues for each level of management and government level, and budget allocation of taxes plays an irreplaceable role in this matter. It is used to determine the extent of financial autonomy of these individual government levels, especially regional and local self-governments. ${ }^{10}$

From a theoretical point of view, the combined model can be divided into:

- a combined model of fiscal federalism with predominant centralising elements in which most of the revenue is concentrated in the central budget from which subsidies are provided to other segments of the public budget system

- a combined model of fiscal federalism with predominant decentralising elements, where the importance of territorial self-governments is strengthened particularly through the determination of a larger part of separate revenue and thus greater self-sufficiency ${ }^{11}$ 
These divisions are already somewhat redundant in terms of public finances because finding a boundary between the two combined models will be rather complicated. It is sufficient for our needs to realise that in the combined model of fiscal federalism, there is a partial decentralisation of public revenues at lower levels of government, the intensity of which varies greatly in individual cases. There is no uniform view of theoreticians and economists as well as political representation in this matter, where the degree of self-sufficiency is often an ideological argument of supporters of one or the other prevailing tendency. ${ }^{12}$

Some authors describe situations where lower government levels have the direct authority to collect and impose taxes and bear responsibility for expenditures as fiscal decentralisation. By contrast, a mere reallocation by allocating centrally collected taxes to lower levels is called administrative decentralisation. ${ }^{13}$

For example, Michal Radvan holds a similar view, pointing to occasional changes in the economic autonomy of municipalities, so that municipalities can decide not only on local self-government expenditure but also on revenue by influencing the amount of tax revenue. In his opinion, municipalities are not able to correct the amount of tax revenue, except for local taxes and real estate taxes. According to him, everything has been set by the legislator in a fixed manner. ${ }^{14}$

On the other hand, it is not appropriate to narrow the issue of fiscal decentralisation to only the fiscal competence of territorial self-government units, i.e. the issue of local taxes. A manifestation of fiscal decentralisation is also the budget allocation of taxes, even though it is a decentralisation stipulated by law according to well-defined criteria. The specified shares of the allocated tax revenue were not determined by the legislator arbitrarily. It is a continuous development of the level of financial autonomy after the restoration of territorial self-government in our territory after 1990. Own revenues gradually began to form the dominant part of the total revenues, especially for municipalities. Already in the 1990s, authors summarised the tendencies of the territorial budget regime as compared to the previous state to the following points:

- strengthening the financial self-sufficiency of territorial budgets and reducing their dependence on subsidies from the state budget

- attenuating the claim-related requirements of municipalities

- achieving greater autonomy and responsibility of local governments in the budget regime

However, we can speak of these as partial changes that are the result of processes taking place within the public administration and, on the basis of these arguments, we can divide the fiscal decentralisation into:

- fiscal decentralisation carried out by tax sharing, when the legislator sets out shares in tax revenues to be allocated to specific segments of the budget system and their components

- fiscal decentralisation carried out by assigning taxes, when the entire tax revenue is transferred, i.e. assigned, to specific segments of the budget system and their components 
From the above, we can conclude that fiscal decentralisation can take place through tax assignment or tax sharing, depending on the budget allocation, to which public fund the tax revenue flows to and in what amount. Budget allocation is one of the tax structural elements because it determines where the tax revenue flows and which budget reports it in its revenue. ${ }^{15}$

Depending on whether only a single public budget is a recipient of tax revenue or the revenue is split between more segments in the budget system, we distinguish between shared and assigned taxes.

Assigned taxes are the revenue of the relevant tax which flows exclusively into the budget of municipalities and regions. These taxes currently include:

- real estate tax (the entire revenue goes to the municipality budget)

- corporation tax (where the taxpayer is a municipality or region, with the exception of a withholding tax at a special rate)

Shared taxes are taxes the revenue of which is divided into several segments of the public budget system by percentage, i.e. precise shares are set either according to a mathematical formula that takes account of certain reallocation criteria or depending on the place of tax origin, i.e. where the tax is collected. This means that only the share of the national tax revenue goes to the municipal and regional budgets. These taxes currently include:

- value added tax

- personal income tax (advances on this tax)

- corporation tax (except if the taxpayer is a municipality or a region $)^{16}$

\section{Legal Framework and BAT Relevance}

The fact that the income of territorial self-government unit budgets includes, among other things, tax revenues and their shares according to a special law is regulated at the most general level by Act No. 250/2000 Coll. on Budgetary Rules for Territorial Budgets, as amended. Consequently, the tax allocation of taxes is regulated by Act No. 243/2000 Coll. on Budget Allocation of Revenue of Certain Taxes to Territorial Self-Government Units and to Certain State Funds (the Act on Budget Allocation of Taxes), as amended. This act, comprising only eight articles, identifies two major issues:

- which tax revenues are transferred by the state to the territorial self-government units completely, or a share of tax revenues to territorial self-governments is determined

- establishing criteria and a method for calculating the share of each individual municipality and individual region

It is hard to imagine its practical application by simply reading the text of the act. In fact, formulations verbally express a mathematical conversion, the expression of which is rather complicated for obvious reasons. In order to understand the Act on Budget Allocation of Taxes, a detailed analysis of individual provisions is required, using many materials containing, among other things, data on the performance of individual territorial self- 
government units in the time series. It should be noted that budget allocation is always a matter with disputes over the way taxes are reallocated within the budget system and that there is a very frequent debate on the fairness of the system set up. At the same time, we can state that tax allocation, including reallocation of taxes, can be described as a legal and economic and political issue the opinion on which is not uniform. ${ }^{17}$

The most important facts about budget allocation of taxes are as follows:

- Tax revenues constitute a major part of municipal budget revenues (roughly 55-60\%).

- Tax revenues of municipalities are not assigned.

- Municipal authorities decide on the use of tax revenues.

- Tax revenues of municipalities are the basis of both economic and financial independence of municipalities from the state.

\section{Possibilities for Changes to the Budget Allocation of Taxes Acceptable De Lege Ferenda}

One of the objectives is to summarise the findings based on long-term monitoring of the issue and to reflect on some of the related aspects. Allocation of taxes is undoubtedly a matter of political nature. Specialists in the field generally enter the discussion only based on set model analyses. Even the specialists do not have a uniform opinion on the reallocation of shared taxes. ${ }^{18}$

The debate on the topic of budget allocation of taxes is definitely not over by adopting the latest amendment. It is assumed that this will be a solution for a year or two, followed by the incorporation of a budget allocation institute as a structural element into individual tax laws.

As far as the current system is concerned, it could be adjusted in the following way to better match the real needs of municipalities with the real costs of municipalities related to the delegated and autonomous authority of public administration:

- establishing a criterion of the built-up area of a municipality

- reducing the weight of the municipality's assessment criterion (or completely abolishing it) and the need to adjust the weight of other criteria (creating a balanced system of criterion weight that would correspond to the amount of costs associated with the given criteria)

- reducing the weight of population criterion at the expense of other criteria

- including the share of consumption and environmental tax revenue in BAT

- setting a single percentage for determining the share of municipal budgets in shared taxes to reflect the inclusion of other taxes ${ }^{19}$

From the point of view of the budget allocation of taxes for regions, the funding of education still seems to be the most current adjustment. At this point, there are two solutions that can be considered:

- the first option would be to increase the total share of regions in shared taxes, with the region continuing to reallocate that part of the funds that would represent the direct costs of education according to the stipulated schedule and, at the same time, 
to increase the total share of municipalities in shared taxes to the extent of the current subsidy provided from the state budget in the aggregate subsidy relationship for the partial reimbursement of operating expenses

- the second option would involve increasing the total share of municipalities and regions in shared taxes for the new percentage to include the direct costs of education by the founder, as well as subsidies for partial reimbursement of operating expenses in the case of municipalities ${ }^{20}$

The first option appears to be a compromise where the advantages prevail. It would strengthen the economic impact of territorial self-governments on the educational organisations they establish. On the other hand, the concern about the municipal self-government having too much influence on rewarding teachers, especially in preschool and elementary schools, would be eliminated. ${ }^{21}$

\section{Conclusion}

Tax revenues are among the most important and largest sources of funds for municipalities and regions. Without tax revenues, municipalities and regions could hardly finance their operations and other public administration activities. Therefore, it is important to set up a BAT system to meet real needs, to be stable and not to favour a particular group of municipalities or regions over others.

In spite of the great criticism of the current BAT system introduced in 2008, we must recognise that this system has brought much needed stability into the funding of municipal systems and that it has removed unfair differences in revenues of cities and municipalities of relatively the same size. Financing of municipalities was linked to decisive tax revenues, which ensured their continuous growth. Yet the municipal budgets, especially of small municipalities, are not enough to cover all the costs associated with public administration. Therefore, it is necessary to keep developing the current system and to introduce criteria that would be able to reflect the real costs that municipalities have in the public administration. ${ }^{22}$

It is clear from the above text that the development of the budget allocation of taxes and their significance for municipal and regional budgets in the Czech Republic is positive, given that the budgeted revenues can be quite easily estimated for each municipality and region. This property of the current BAT is crucial because municipalities and regions have the possibility to estimate revenues and to adjust costs to avoid large indebtedness. The partial amendments to the Act on Budget Allocation of Taxes introducing various criteria for the reallocation of taxes strengthen municipalities and regions as they ensure their permanent financial basis, and it can be concluded from the above that the hypothesis stated in the introduction has been confirmed. 


\section{References}

1 Milan Bakeš, Marie Karfíková, Petr Kotáb, Hana Marková et al. Finanční právo. 5. upravené vydání [Financial Law, $5^{\text {th }}$ revised edition], 548 (Praha, C. H. Beck, 2009).

2 Ivana Pařízková, Finance územni samosprávy [Finances of Territorial Self-Government], 238 (Brno, Masarykova univerzita, 2008).

3 Martin Netolický, Vztahy mezi články rozpočtové soustavy [Relationships between Budget System Segments], 104 (Brno, Tribun EU, 2010).

4 Netolický, supra n. 3, at 102.

5 Ibid. 105.

6 Romana Provazníková, Financováni mèst, obcí a regionů [Financing of Cities, Municipalities and Regions], 86 (Praha, Grada Publishing, 2007).

7 Act No. 243/2000 Coll. on Budget Allocation of Revenue of Certain Taxes to Territorial Self-Government Units and to Certain State Funds (the Act on Budget Allocation of Taxes), as amended.

8 Petr Mrkývka et al. Finanční právo a finanční správa, 1. díl [Financial Law and Tax Administration, Part 1], 397 (Brno, Masarykova univerzita, 2004).

9 Romana Provazníková, Financováni mèst, obcí a regionů. 3. aktualizované a rozšiřrené vydání [Financing of Cities, Municipalities and Regions, $3^{\text {rd }}$ updated and extended edition], 109 (Praha, Grada Publishing, 2015).

10 Netolický, supra n. 3, at 107.

11 Jitka Peková, Jaroslav Pilný, Marek Jetmar, Veřejná správa a finance veřejného sektoru. 2. přepracované vydání [Public Administration and Public Sector Finances, $2^{\text {nd }}$ revised edition], 172-173 (Praha, ASPI, 2005).

12 Netolický, supra n. 3, at 107.

13 Provazníková, supra n. 6, at 40.

14 Martin Netolický, Vztahy mezi clánky rozpočtové soustavy [Relations between the Cells of the Budget System], 107 (Brno, Tribun EU, 2010); Michal Radvan, Ekonomická autonomie obcí v České republice [Economic Autonomy of Municipalities in the Czech Republic], 137-147, in Interakce ekonomie, managementu a práva prí rozvoji regionü [Interactions of Economy, Management and Law in Development of Regions] (Brno, Vydavatelství MU, 2006).

15 Michal Radvan, Finanční právo a finančni správa. Berni právo [Financial Law and Tax Administration. Tax Law], 33-36 (Brno, Doplněk a Masarykova univerzita, 2008).

16 Mrkývka, supra n. 8, at 397.

17 Netolický, supra n. 3, 109.

18 Ibid. 178.

19 Cf. Ibid. 178

20 Ibid. 180.

21 Ibid.

22 Provazníková, supra n. 9, at 131. 